\title{
The Permanent Condition of War-And-Peace: From the Total Mobilization to the Absolute Construction of the Event
}

\author{
Žarko Paić \\ Department of Fashion Design, University of Zagreb, Zagreb, Croatia \\ Email address: \\ zarko.paic@ttf.hr \\ To cite this article: \\ Žarko Paić. The Permanent Condition of War-And-Peace: From the Total Mobilization to the Absolute Construction of the Event. \\ International Journal of Philosophy. Vol. 6, No. 2, 2018, pp. 40-54. doi: 10.11648/j.ijp.20180602.14
}

Received: June 2, 2018; Accepted: June 19, 2018; Published: July 10, 2018

\begin{abstract}
In the present consideration the author tries to explain on three levels a fundamental shift which occurred and changed the dynamics of the binary opposition of war and peace and the globally defined area, the post-national sovereignty. Those levels are: (1) transition from the metaphysics of modern history to the production of bio-political power on a global scale between the "Empires" (United States, Russia and China) against "rogue states which calls into question the ontological definition of the modern war as a civilian, guerrilla as warfare or ethnic conflict; (2) definition of the world as a total mobilization (techno-science and capital) which necessarily leads to the possibility of total war as the absolute construction of events on a planetary scale; (3) review of the Enlightenment's ideas of Kant's "perpetual peace " in correlation with the condition of permanent "state of emergency" on a global level, which break up the Manichean logic "either war or peace", because we are living in an age characterized by the logic of war and peace in the intervals it constructed crisis of the global security. Therefore, the question of "human nature" as good or bad does not make decisive philosophical meaning, and even theological problem, because the ethics of responsibility becomes only a weak appeal for the preservation of life on earth and the theology of salvation already assumed the fight against evil in the form of negative theodicy. What, then, is left of the idea of not only world history but also of the different versions of the "just war" at a time when terror, total control and politics should decide on events in the world? The answer could not lie in the pseudo-humanization of the world and the inflation of ethical doctrine as a treatment for a technology-designed apocalypse. Instead of utopias and apocalyptic narratives, the solution lies in rethinking the constellation of techno-cybernetic thinking as the dangers that allow conditions of "total mobilization" and "absolute construction".
\end{abstract}

Keywords: Permanent Condition, Total Mobilization, Planetary, Biopolitics

\section{Introduction}

If there is no war, there is no history. Haven't this premise been given in advance to a mythical discourse that presupposes a triumph: the golden age - the fall of the obscurity of history - redemption? It is not necessary to emphasize specifically that there is something almost metaphysical inborn in different world civilizations with regard to the thinking of the life of man on Earth. In addition, history has come to its perfection and fulfillment in its goals and purposes to the age that determines the unconditional rule of what Ernst Jünger named total mobilization of planetary technology in the 1930s. [1]. This certainly does not mean that there was a state of "perpetual peace" in the sense of Kant's postulate of a cosmopolitan order. The conjunction if which we use here does not mean a sophisticated figure of thought. It is not about questioning without a response to the principle of un-knowledge of what this might be the subject of discussion. Instead of such skepticism full of arrogant scientific habits of processing data in the service numbering that enlarge the knowledge of the world must be recognized that the relationship between war and peace can no longer be adequate thinkable from the very heart of metaphysics. Some of its core concepts like cause/effect and determinations/consequences do not seem to apply to a new set of relationships. Because if there is no 
longer history, as the most significant French interpreter in the 20th century Alexandre Kojève pointed out in comments on Hegel's Phenomenology of Spirit in his book Introduction to the Reading of Hegel, which is still to be left? Thus, it seems very often that the footnotes of the most important philosophical books are even more significant than the main text. In the case of this overwhelming book to understand the existential turn in contemporary thinking with all the farreaching consequences according a different notion of metaphysical questions, we should be able to remember that one footnote of the book has been so remarkable that this is a reason why, for instance, Agamben tries to answer the question of differentiation between animals and humans, takes the beginning of the post-historical situation. In it, technology determines the conditions for further development of man. But this development goes beyond the boundaries of the human being and becomes the third concept in the way of the animal over man to the machine. [2]. Before we make the full note of this famous footnote of "the end of history," it has to be said that the echoes in the contemplation of contemporaneity are multifaceted. Well, it ranges from the notion of politics and technique, art and play, and it also covers the area of psycho-technology of life itself in the difference between man and animal. Anyway, whoever tries to think of the difference between war and peace in the ontological sense of the word has to clear the reasons why instead of binary oppositions, dialectical contradictions and negations on which the speculative thought of modernity was strongly built, what can come after history can no longer be preserved the difference we are talking about. Why instead of this important historical epochal difference between two states, not their indefinable 'be', it should be easy to say that we live in an age without "time", the age that in the planetary-global determination is being performed by the logic too-either. And it only means that everything is not only possible but even more necessary and that reality is nothing but a constant transformation of the potential necessarily and vice versa with all the consequences of this thought and worldly chaos. So, if it is no longer a matter of logic either-or, then everything must have been thought in that way since Nietzsche has opened a new assemblage in the context of constant becoming (Werden), as well as in the processes of change without end, and finally in the control of the spirit's own life when posthumanism and cybernetics govern over uncertainty and un-determination of Nature of the things to come. Thus, in this footnote, Kojève says the following:

"The disappearance of Man at the end of History is not a cosmic catastrophe: the natural World remains what it has been from all eternity. And it is not a biological catastrophe either: Man remains alive as an animal in harmony with Nature or given Being. What disappears is Man properly so called - that is, Action negating the given, and error, or, in general, the Subject opposed to the Object. In point of fact, the end of human time or history - that is, the definitive annihilation of Man properly so called or of the free and historical Individual - means quite simply the cessation of action in the strong sense of the term. Practically, this means the disappearance of wars and bloody revolutions. And the disappearance of Philosophy; for since Man no longer changes himself essentially, there is no longer any reason to change the (true) principles which are at the basis of his knowledge of the World and of himself. But all the rest can be preserved indefinitely; art, love, play, etc., etc.; in short, everything that makes Man happy." [3].

What if, however, the history of the end of the era of "the disappearance of wars and bloody revolutions" leaves something else ultimately undefined and not just "everything that makes Man happy" in which Kojève includes art, love, game, etc.? Can we remain undefined under what extends the agony of reality to an even greater extent than the all-time creation of destruction in the time when the "revolution" and "civil wars" were in the service of flywheels of historical "prosperity" and "development"? Both questions are actually the same. It can be formulated as follows: can it be defined at all if it is absent from a logic that allows it to be indelibly determined from something else rather than from itself? It is well-known that the most significant political theoreticians of the 20th century - Carl Schmitt, Hannah Arendt and Leo Strauss - sought to consolidate this indomitable and insignificant human being. To him, however, belongs the possibility of a radical change of mind, starting from the relationship to the "being" of the activity of that political, not just of its metaphysically committed circumcision in the sense of enduring purpose in it as understood in Aristotle. War and revolution which were discussed are nothing autonomous, irreducible in itself and anything running from outside. These are the events of the fallen state of the being. However, even in this existential interpretation of Hegel's theory of history, the events are available at the disposal of History as such. The reason why is history here absolutized lies on the border between the being and the event. Being without history cannot be "more", it is not one that we do not have each other as authentic words of telling about what "is" and what is "going on", it might be necessary to establish clear criteria according to which the thinking of history as a Being and to history as the event takes place outside and within the metaphysics itself. What does that really mean? Only that without history in the sense of its destiny and the unbending of insanity cannot be "more" reasons for various "wars" and "revolutions". Nor can it be what history has given the odds of absolutization, regardless of whether it could be an idea, work, freedom, play, life, and so on. If there is nothing in it that is enough to serve anything else, and it is, God, man, and the world in the sense of the metaphysical framework, everything slips into the abyss of non-existence. All is thus doomed to duration not to "be". Also, the internal starter is missing in the direction of the unknown. Only then can we speak about the chaos of contingency instead of the meaning of history. Its last act would be exactly what Kojève so praiseworthy magnified the transformation of history into Hegelian-speaking new "zoo" on Earth. However, the consequences of this are the emergence of a techno-genetic park with an extremely dubious way of founding a "new man." [4]. 
If we look more closely, we can only argue that the historicity of history cannot be reduced to the war or military in its two-directional movement: (1) a circular that corresponds to the artistic understanding of the meaning of the being on earth differing from what belongs to gods and animals; (2), which in accordance with the Christian-modern concept of the "new" concept of "advancement" and "development" is no longer performed in the activity of human creativity (creatio, poiesis). Now it's all about getting into what goes beyond human projects. As a character of the technical constellation of the being, it might be unstoppable to penetrate the deployment-moving of the human to the inhumane, the earth to the universe, the techniques and the technology into the technosphere. In the first case, the mythical saying gives the narrative of its "destiny". And that means that human freedom has its limits in its finality and death. Hence, history is essentially confined to the sovereignty of the decision. Its peoples are everlasting from the territorial necessity of displacement/settlement of the nation necessarily in brutal and dangerous conflicts. They originate from tribal wars for the land until the occupation of the sovereign territory of the Other in the name of "natural law" and the will to power. The interruption with this "limited" function of the territory war in the circular movement of the old peoples emerged in Europe on the ruins of the Roman Empire. In this way, the age of the rule of the metaphysical subjectivity of nation-states is established. But the war in this understanding can no longer be, Hegelianic spoken, the heroic confrontation of man with nature in the struggle for dignity and power in the form of One or Multiple (monarchy, republic, democracy). Instead of this politicalanthropological determination of war as the means/purposes of the will to power, as it is determined by Machiavelli and Bodin to Hobbes, the work represent a technical turn of history. With it, the meaning of war can no longer be something that is only in function for other purposes and goals. Whether we are faced with a war for freedom and a just war of the oppressed nation against the evil one Lord/Ruler in the midst and on the edge of the Empire (anticolonialism and postcolonialism), or, alternatively, with a civil war on a global scale between nation-states in the form of imperial power as it was in First and Second World War in the 20th century.

In this regard, I will strive to show a fundamental turn in the way the dynamics of binary oppositions of war and peace take place in the planetary defined space of post-national sovereignty:

(1) the transition from metaphysics modern history with binary machine of the nation-state in the biopolitical production of power on a global scale conflict between the "empire" (the United States, Russia and China) against "rogue states" which calls into question the ontological definition of the modern war as a civil, guerrilla or ethnic conflict;

(2) the definition of the world as a total mobilization (techno-science and capital) which necessarily leads to the possibility of total war as the absolute construction of events at the planetary level;

(3) re-examining the enlightenment idea of Kant's "perpetual peace" in correlation with the state of the permanent "extraordinary state" at global level, leading to the fact that instead of Manichean logic "either war or peace" we live in times characterized by logic either war and peace at intervals of constructed crises of world security.

For that reason, the question of being "human nature" as evil or good does not seem decisive anymore in the philosophical matters, nor in the theological problem, since the ethics of responsibility becomes only impotent with the appeal to preserve life on Earth, and the theology of salvation also presupposes the fight against evil in the form of negative theodicy. The question of the rule thus becomes the question of separation of power as auctoritas and potestas of the new era (politics and rights in the narrow sense of the word). It is therefore obvious that the modern state seeks the unity of these powers. The reason lies in that without synthesis it cannot achieve absolute authority over the territory in the struggle with other states. This is at the same time the reason why in the 20th century, after the Second World War, history in the political meaning is understood through the attempt to fulfill universal world state. It loses the character of statehood because it no longer has the territorial sovereignty of a modern nation. Instead, its mission might be reduced to the regulation of the interest of anything that is no longer political from as they are science, technique, demography, economics, and culture in the wider sense of the word.

\section{The Chaos and the Logic of Exception}

The well known and distinctive Clausewitz's assumption that the war is a continuation of politics by other means represents a perfectly clear metaphysical framework and understanding of the being as a will to power in the modern times. In this way, Heidegger has completely destructed the meaning of that definition in his Black Notebooks (Schwarze Hefte). For example, the definition neglects that the essence of the political cannot be independent of the outcome of the modern times without the "legitimacy" and the "legality" of action is the technique itself. In the second turn, Heidegger will show that the contradiction of so many repeated definitions of the modern war derives from the impossibility of establishing the logic of the subject and object ("master" and "servant", "winner" and "defeated") at the end of the entire epoch of the modern era. If the war became "total" in the 20th century, then politics could no longer be a subjectsubstance of warlike action against the Other as it was customary in antique, medieval and modern ways of occupying the country. What should be changing circumstances alike with the loss of power policy? At first glance not so much. The politics become a means of establishing a techno-scientific drive to global capitalism. After the horrific experiences with totalitarianism in the 20th century, the transition to one's own borders will be followed. The mystery of the work of the "new" era as a performative event of liberty within the limits of the technosphere requires 
the overturning/reevaluation of the legacy of contemporary thinking of politics at all. This is primarily based on the assumptions of the leading theorists of the inscrutability of the political as a decision and as the theory of the exceptional state. But this is, of course, connected to Carl Schmitt. The guideline of his decisionism theory could be described in a way that the political must be separated from the bonds of technology, science, society, economics, culture, and religion. [5]. (It is a binding thought that a "total war" has taken drive of "politics" to be more serious than what looks like in reality because it will not result with the triumph of winners and defeated:

"Fighting like the war it is not the 'father' of all 'things', if this name covers anything that is not in the widest sense, it is nothing. He is never the creator and ruler of the Seyn, but only always of the beings - the Seyn don't designate productio and does not indicate any mastery. Seyn 'is' unchangeable and un-relational - because it is an event in the abyss.'[6].

Keeping track of how the concept of war is derived from Clausewitz to Carl Schmitt is something we should be able to see paradoxically. In the Greek notion, war is determined by the conflict between the cities-states (on the internal level of reaching the freedom of community members) and the conflict between polis and despotism in the Greeks and Persians (on the external border of protection level). Mythical founding of polis as a primordial community of free and equal citizens is not devoid of war devastation and conquest of other territories outside Greece. After all, the beginning of Western history is precisely in those exceptions as the law of exception. It affirms the "necessity" of colonialism by other means. Hence, it is, of course, a war of Achaeans with the Trojans. In Homer's The Iliad, this war becomes the mythical beginning of Western history. We must

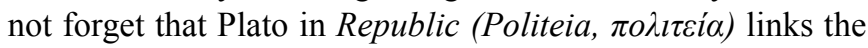
emergence of a democratic order with the civil war between the oligarchs and demos. In a more recent interpretation of the impacts of anger in the planetary period, the war against terror (ism) as the main phenomenon of the post-historical ressentiment Sloterdijk introduces into the discussion the term thymos. What Hegel still calls the need of the subject for its own confession might be the minimal definition of that term. So, the struggle for recognition signifies the will to maintain a subject at the level of history. Hence, it is not accidentally that early Hegel holds that the war in its negativity determines the historical right to the emergence of the state as a confirmation of the objective spirit. The natural right, therefore, is the result of the war, not peace. [7]. From that follows assumption how the war analysis should be inevitably directed in the political struggle for the recognition of the oppressed subjects/actors from states to ethnic groups.

Undoubtedly, that means that it cannot be politically understood in its democratic structure of government without the insight into the psychological mechanisms of the creation of a new subject. In the assemblage of disagreement and emptiness, his identity could be not determined more by the sphere of the mind. The turn appears long before the postmodern obsession with the ethics of psychoanalysis, which is the initiator right to desire as Lacan most radically stated. The psycho-politics of an affective anthropology can thus become a condition for understanding conflict with the tendency of transition to the state of war. [8]. Obviously, the paradox is that policy has to precede politics, but not as a freedom that falls into the waste of power. In this case, the right to conquer other territories is uncannily established by the argument of natural law. This is done on behalf of the political goals of freedom, equality and justice. Thus, it would be not difficult to conclude that the origin of the modern paradigm of war intervention of the West in the global age (the United States and NATO) has been legitimate by arché of history. The Greeks, for instance, come to another place to enlighten them as barbarians inhabited the Arcadian wilderness, granting them further benefits of democratic legitimacy. In addition, it might be paradoxical, therefore, that the right to freedom appears in the sign of contesting the right to sovereignty to one who does not respect the fundamental "values" of universal meaning. Freedom hence arises formally opposed to the logic of power in the name of a request for more power that does not really belong to it. [9]. (There are no significant differences between the ancient Greeks, the imperial Rome, Crusades against Arabs, modern colonialists from England, Spain and Portugal until to modern America. That political is also the essence of the fateful event without rational explanation. That's a reason why it necessary splits between the requests of righteousness and uncanny call of the will to power as Nietzsche argued in his writings. [10].

What is the perversion of the so-called moral values in modern times in the ethics of duty? Only in that what Nietzsche has already clearly pointed out: that morality does not follow its own logic of the Crucified on the cross. On the contrary, moral instinct is rationalized as the power of the other nature of sinfulness. In the name of the will to power, one judges what "is" good, true and just, but not in the name of the good, the truth, and the justice. For that reason, the war of the new era is no longer considered differently from the realism of the nation-state interest. Everything has since been measured by reference to which the means become a purpose, and the purpose is to reach the goal. The only exception to a series of thinkers from Hobbes to Hegel and Schmitt is definitely Kant. His magnificent idea of "perpetual peace", unfortunately, serve only the as a regulatory scope of what usually preaches the authentic faith of Christianity. But as a matter of fact, it must remain essentially politically ineffective. The reason is that it will be a matter of acting in relations between the states, bringing down control, police and internal-security affairs in the cosmopolitan world. For our purpose of considering the relationship between the being and event that war becomes a permanent balance in intervals with peace, thus losing his will that "ontological" has been fixed, Clausewitz, and that consequently the things of thought is true then and for peace, and beyond the dialectical scheme of negativity-positivity, let's go back to what Heidegger claims for the term "totality" and "planetary" 
concerning the modern age. Nobody wins in the "total war". And all others become "losers" too. What does this statement mean? Who are that enigmatic "we"? And it seems undeniable that the "total war" is no longer just about to occupy the territory of the Other (state/race/culture) in an unconditional obedience, the question of the "subject" of warfare in the planetary period of the world requires first and foremost clarification to continue with that concept by using what comes from the historical development of metaphysics itself. The answer cannot be executed without attempting to overcome metaphysics. Within its framework, it appears that what Nietzsche named with sentence "Platonism for the masses“, referring to Christianity as an anthropomorphism of goals and purposes beyond "this world". In other words, the principle of contingency and exception (singularity) give to the event of political real possibility that the war as a "total mobilization" overcome starting from the essence of technology. In Heidegger's critical remarks, with the notion of "worker," "totality," "mobilization", "planetary" and "world state" in Ernst Jünger's philosophical and literary reflections this thought is constantly interwoven through the dense weaving of Nietzschean's origin. At one place we can see, how this become the highest praise for Jünger's achievement of thought:

"What Jünger sees clearer than Nietzsche is what Nietzsche could not yet see in these phenomena since they were concealed in reality. In whole, these techniques appear as a fundamental way of directing and securing a reality as a will to power./.../ What Ernst Jünger, however, does not see because it cannot be seen because it is only available in the thinking is the essence of the will to power as the reality. It is the essence of 'reality' as the essence of being. This is, moreover, the definition of being in a beingness that develops from its beginning as Being." [11]

Seeing and thinking obviously designates the same, but essentially different. If we are trying to understand why the "total war" essentially goes beyond the historical sense of conflict between nations and states becoming "more" than the war as such, then it must be noted that the difference between the end of history and what is still undefined in the remnant of the end of the history of the Being and the beginning of an uncomplicated event raised as an abyss. The abyss is furthermore expanding into contemporaneity. When "wars" and "revolutions" lose the character of world events it does not mean that their sense is below the level of the worldliness of the world. It is that the notion of "the world" after the experience of the "total war" and the centuries of totalitarianism loses its metaphysical rank. This loss must somehow compensate. And so, instead of world-historical events with the ideas of "progress" and "development" of freedom consciousness, which is a clear Hegelian trace of speculative-dialectical thinking, the time of "globality" and "planetary" is finally born. Speculative dialectic concept and ideas replace techno-genesis and new worlds which are virtually designed. This does not mean that the "wars" are neutralized and suspended in essence of what has a political and historical legacy of the transformation of the state. The difference between world history and the global-planetary state is determined by the difference in the way of thinking the action of metaphysics and its shattered heritage. In this respect, it can be said that "wars" and "revolutions" today only serve to consolidate the geopolitical power of the new empires in the various techno-scientific constructions of artificial life. Instead of the space for the development of the idea of freedom from Greeks and Romans through the Middle Ages to the ending of the history of the end of totalitarian order in the 20th century, the daily struggle for post-imperial "sovereignty" become a new task. So, that means that it might be only the question of what is left of the metaphysics of the history of the will to power and the nihilism of "total mobilization" in the essence of global capitalism. [12].

All terms with which Jünger sees what Nietzsche could not saw because the matter concealed relates, therefore, belongs to the technical organization of the being as a will to power. If it becomes technically complete, a fertile soil is created for earth's devastation. It is entirely wrong to declare this setting "reactionary" in relation to the unconditional right to perfect man in the horizon of the future. The problem should be considered in a radically different way. The technique is not the result of the ontology of society and culture in the sense of derivation from an original set of directives. On the contrary, when Being is understood from the technical constellation of the world-historical path to the arrival event, it is only in the coming age that the time is reduced to "actualization" and consequently to "punctual momentum". The loss of original time will now be compensated by narrowing the spatiality in which events flow. The impossibility of information signifies a new concept of this complex reductiveness of the Being. Its meaning is not just compression instead of stretching in all directions. The result should be that history as an informational "black hole" responds to the challenges of oblivion of one's own memory, so in contemporary societies, the main problem becomes the distinction between memory and recollection. First, memory belongs to the unconscious structure and refers to the loss of relation to the proxy because of the "present" rule in the form of virtual updating. Secondly, recollection makes a network of data controlling timing by means of a technosphere that "memorizes" every event by storing it in digital machine files. In the newer theories on the trajectory of complexity, singularity and contingency, time becomes a construct of reality. Therefore, the modal category of features should be transformed into the virtualization process. The philosopher with whom has to come to the digital age is surely Deleuze, and his distant predecessor was Leibniz. [13]. (Hence, it is not the space of freedom, but the closeness of power within a technical way of thinking. Three major categories are represented here as follows:

(a) calculation,

(b) planning and

(c) construction.

The calculation determines the practical or pragmatic way of thinking; planning, however, refers to the rational editing 
of the space-and-time within which life-control processes are being conducted; construction, ultimately, assumes the act of creating a "new" based on a mechanically organized system and method of producing new artificial worlds. These three categories are crucial to understanding being a technique that makes the condition of "progress" and "development" of science possible. The emergence of the "new" cannot be described differently than the way Ernst Jünger did dramatically in the conclusion of his book $A$ Worker (Der Arbeiter):

"Entrance to the imperial space precedes the temptation and determination of planned landscapes that cannot yet be imagined today. We are approaching astonishing things. On the other hand, the democracies of work that are being processed and transposing the content of the world known to us are the outlines of national arrangements beyond the possibility of comparison. Nevertheless, it can be predicted that there will be no more words about work or about democracy in our established sense. We are just about to discover the work as an element of fullness and freedom; it also changes the meaning of the word of democracy when the fatherland of the people appears as the bearer of a new race." [14].

There is a need to distinguish three ways of historical "progress" and "development" techniques: (1) the technique as a means of exploiting the resources and potential of the Earth in the industry, thus making human work a condition for the wealth of "people" and "states" (national or political economy of capitalism); (2) modern technology as the purpose of the foundation of social "progress" and "development", making history neutralized in the liberaldemocratic understanding of man as "citizen" and "consumer", while the "worker" is replaced by a machine; (3) the contemporary technosphere emerged from cybernetics and informatics as the reign of the inhumane in the form of A-intelligence, which goes beyond the causality and vigor of history and replaces interplanetary lurking of a singular "living machine,"[15]. By introducing this distinction it would be possible to speak historically-epochally about "wars" and "revolutions" starting from the contemporary condition. Jünger calls it the most famous expression for the essence of what is "no" but is "happening" due to the mode of transformation of the being into the virtual update event. This term determines the demise of work and democracy in favor of the permanent process of "total mobilization" (labor, capital, information). In this respect, the "progress" and "development" of human history are identical to the technological-evolutionary path of building-disintegration of a living machine. If the technique belongs to nature, technology to culture, then it is techno-genetic beyond all the differences between the earth and the sky, the struggle and being of God and man, creation and production. Since the technosphere can be understood only as autopoiesis in the life self-confirmation "new nature", it is possible to assume that the time of "total mobilization" means the war in the "big space" (Großraum). The people and states are no longer fighting here. [16]. The machines of destruction and demolition referring to the logic of technosphere overwhelm the inhumanity as far as no other or different from mankind's humanity. It might be the event of the apocalyptic openness of nothing itself. In its two forms, devastating and creative potential, nothing completes the history of the wars and the revolution of the metaphysics which belongs to the West. The nihilism of world history after the "total war" becomes a planetary destiny. With Schmitt and Jünger this was the deepest thought made by Heidegger itself in the late 1930s.

But, from Heidegger's point of view, what is above here controversial at the end of metaphysics of subjectivity? With it the history of wars almost disappears between "nations", "states", "races" and "cultures". Why? Simply because overcoming subjectivity signifies simultaneously overcoming to being a modern society. It is happening in that way that in liberalism a state has its last purposes/aims in the enterprise economy. So, these purposes are categorically entered into the appearing essence of planetary globality: infinity, measureless, number, computation, flatness, homogeneity, emptiness. It is not a "total war", therefore, just the astonishment of the destruction and devastation of the Earth with the "progress" and "development" of planetary technology that switches the power of weapons into the space of heaven and air, rocket systems and satellite control of destruction systems. Not at all, rather that is something more significant than leaving the earth as rooted in pervading the Being as such. The transformation of the war from "rest" into the posthuman state of the "Star Wars " was announced in the works of two of the most significant representatives of the so-called German Conservative Revolution (Konservative Revolution) from 1920-1930 - Carl Schmitt and Ernst Jünger. [17]. (In favor of the essence of the thing itself, we must also connect right there Martin Heidegger. In spite of this movement and of the special role in the closeness and differences between the Nazism and the 1930s, Heidegger's analysis concerning the essence of technique and "total war" is still far-reaching stimulating for the current discussion. [18]. There remains, however, a lack of clarification of the difference between world history and what is still undefined in terms of "planetary" and "global" concepts. It seems that in the "Big Space" (Großraum) we enter into what is inbetween: on one side of the Being and events, on the other side of the earth and of the sky. If the air strikes of the allies during the First and Second World War on German cities overruled any possibility of heroism and adventures in the realm of nihilism, because the planes and megatons bombs do not embody the struggle to death between the living for recognition, then it should be clear that the notion of totality (mobilization-work-technique-capital-science) necessarily leads to the universal destruction of the planet and the globe. Apocalyptic literature that talks about it are certainly one of the German novelist and essayist Hans Erich Nossack and on his trace the literature written by W. G. Sebald. [19]. The end of history in a totally different meaning than that of Kojève in the interpretation of Hegel is no longer related to the end of the possibility of fulfilling the idea of freedom. It's the end of the possibilities of any illusion of "naturalness", "inborn", 
"purpose", performing plan constructed in God's mind (positive or negative theodicy):

"The perfection of the technical means of power is in the ultimate state of purpose and possibility of total destruction. (...) Already in the last war, there was a zone of destruction whose scene can only be described if compared to natural disasters. (...) The romantic thought is that social contracts can spit the rampage of these energies, their application in the struggle for life and death. The premise of these thoughts is that a man is good - but a man is not good, rather good and bad at the same time. In each budget that needs to be passed the test of reality, it must be included that there is nothing that man is not capable of. Indeed, it is not determined by moral regulations, it is governed by laws."[20].

The war in the age of "planetary" and "globality" goes into state-between two equally indefinite events: the former might be the struggle for post-imperial sovereignty and the latter indicate a struggle for the establishment of the "world state" with terror and the state of exception. The transition from one form to another still does not mean that the war should be considered differently than the way Clausewitz has defined it. Less important, however, is represented by the continuation of imperial-totalitarian or imperial-liberal politics by other means. [21]. What causes special attention and thought of distress could be the definition of politics as something inexperienced close to warlike, military and warfare as such. So, Schmitt's theory of partisan or guerrilla war against the world order as a "universal world state" denotes only a continuation of politics by other means. [22]. (In both cases, we encounter a negative definition of the concept of political and concept of war. What gives the "world war" its worldliness? Nothing but the transition from the form of territorial sovereignty of the European nation-states, which Jünger has described as "the order of Baroque states" in the form of imperialism. It is, therefore, to be said that planetary nature determines a condition of globality. No doubt, the symbolism of planetary power loses the features of the grandeur of European sovereignty, which has inherited it in touch with the eastern despotism orders and the theocracy. Those are, of course, symbols of the sovereignty of power embodied in royal palaces, gold and silver, swords and a serpent in symbiosis with the prerogatives of the divine authority of ecclesiastical authority. When sovereignty breaks down and replaces the symbols of total control, in the foreground comes the picture of the globes, the abstract figures of the Earth's territory and the celestial spheres. Globality is signified the world-historical event in the era of scientifical-technological development. [23]. (In fact, after the United Kingdom, the only two world-historical empires of the 20th century are America and Russia. What approaches them despite the ideological-political differences is something "third." Namely, the state as an empire at the end of modernity is exactly that what Kojéve in correspondence with Schmitt in 1955- 1960 called "universal and homogeneous state ". And that means that the differences in the mode of governance are only deployed into a space of culture which stores the idea of the speciality of "lifestyle" and the (national) identity. If we keep this in mind, then it is no longer acceptable to speak of "wars" and "revolutions" only in the meaning of political events that have big opportunity to change a path of world history. The concept of world history paradoxically became the union of concept and reality only in the 20th century. Indeed, only to the effect of "total war" in First and Second World War has become possible to establish what links the centre and edges. The world as a nascent event of war has been elevated to the spatial level. The check with matching processes that Deleuze and Guattari call deterritorialization / reterritorialization. [24]. (But not far from the truth, it is a setting that all after these events have represented just a continuation of the technique by other means. Both politics and economics, and culture and science, and religion and art cannot fulfill their mission unless they are faced with the aporias of the loss of the world and the history in the age of cybernetics which controls the life itself. Instead of metaphysical illusions about the origins and purpose of the issue of the features of wars "today" seems pretty much more appropriate to show why the world replaces with planetary movement, and history has lost its essence in the simultaneity of globality. Why, therefore, instead of the classical philosophical question of what is something (quiddittas), in this case, war and peace, is to reverse the direction of the questions and explore how the being and beings are emerging (quoddittas)? We can see that its assemblage has been transformed into a process of destruction and creation of a "new" as a case, an indefinite and an exception. How, then, to explain that the end of metaphysics represent the openness of a network of events that to be questioned the overall notion of the relationship between political and politics towards the "phenomena" of war and peace? In other words, the disappearance of history designates the time of the permanent war and peace. But this is the uncanny assemblage of something that essentially changes the whole psychopolitical and geopolitical network of the meaning of what we call the "world," although it might be obvious that this term can no longer be valid for what is actually happening. So, what it should be like and how does it "happens"?

\section{The End of Sovereignty and Power of "Big Space" (Großraum): "Wars" Without a "Revolutions"}

The philosophical approach to "war" and "peace" must include what is metaphysically enduring and what is missing at the epochal finitude of the being. One cannot do without another. That's why it's not about bare binary oppositions. It was clear in the pre-Christian era of Greek philosophy. Already in the designation of what moves in space and time, there is the presence of action and non-action, the power of penetration, and the power to stop the entire process. Greeks used the word polemos (Пó $\varepsilon \mu \rho \varsigma$ ) to sign Goddess of war, which according to Pindar was the daughter of the god Alala. In a relationship with other gods, the same meaning as Ares 
becomes synonymous for the angry god of war. But polemic is not aggression in the sense of wanting to destroy an opponent by his physical removal. From the polemical relation to the Other (ego) as a subject named "I" get the recognition of my own power that in tendency-latency, of we might to serve with Bloch's terms is meant to provoke an unclear fear of the disintegration of the order. Therefore, war encompasses a condition of peace, not vice versa. Paul Virilio is indeed right when in one of the talks with Sylvère Lothringer in the book Pure War claims that "total war" even after the end of the Second World War did not stop. Its only other forms were very active until nowadays. The transformation in the "cold war" between the US and the USSR, in the anti-colonial, and guerrilla 's wars which and due to the progress of biotechnology becoming an "informatics bomb" or introducing into the planetary leadership of the global war basically has been a sign of the constant and permanent arming process. But instead of including the nation-states, what is happening now might be determined by the non-reciprocal relations of worlds empire network which is permanently in the conflicts with renegades ("rogue states") from the "new world order." [25].

What comes out of it should be nothing but ambiguity and contingency. The inability to positively define the war beyond the logic of metaphysics of the eternal struggle for recognition against the Other, as Hegel did in Phenomenology of the Spirit, creates totally paradoxical relations. War is no longer the oppositions of peace and vice versa. In the traces of Jünger and Heidegger, Paul Virilio in its deliberations articulated the essence of contemporary dromosphere - main term for acceleration of civilization that cannot establish a distinction between "progress" and "development". That returns us to the starting point of the problem. [26]. Indeed, it seems that the war in the state of peace within the technically marked spaces of globalplanetary has its "pause" precisely because the machine of the techno-genetic constructions of the event requires a continuous production of the either-or in between Being and events. Therefore, it is thus possible to get between "totalitarian" and "globalitarian" war. Since globalization is enabled primarily by the development of telecommunication systems whose condition is based on finding the internet, then it becomes obvious that the mere social phenomenon such as A-intelligence strategies, artificial life, maps of the human genome and the posthuman condition, as well as cloning project in conjunction with the militaristic logic of the empire and the techno-scientific drive speak of the essential inability of man and his freedom of disobedience. No doubt, we are faced with the conceptual turn and must say: it is no longer the oppositions of war and peace and vice versa, but we have a permanent war-and-peace mode of action of global capitalism. The anthropic way in which is going on the reign of being as an occurrence in the event of an absence of timelessness has far-reaching consequences.

Global capitalism is thus triad what Jünger named total mobilization of work, technology and industry. But even this analysis is today outdated by the nihilism of a famous thinker-writer because it is no longer time of absolute rule of the "worker" (der Arbeiter). This "figure" (Gestalt) does not belong to society or to the state but is produced from the very essence of modernity and capitalism. Here we can get a reminder of Marx's analysis in the Grundrisse where he spoke about the process of automation and constant scientific-technological investment in making profits. The astonishment of "progress" and "development" has been, therefore, not the result of a social achievement of a human in the sense of total rationalization of nature. From the logic of the new technology, which precedes the scientific abandonment of things, the possibility exists that the features of "citizens" and "workers" in a developed modern (industrial) society will substitute for that "image" which has no character of exaltation and anger, boredom and survival. In the place of these historically-played "characters" comes from what Heidegger in Being and Time (Sein und Zeit) called "the They" (das Man). As we should be able to see, it is obviously the structure of the Being-in-the-World (In-derWelt-Sein) in the process of loss of projective selfhood. Therefore, we could not express accidentally that Heidegger's comments regarding the Junger's Worker (Der Arbeiter) show that all the characters/figures are actually transient and changeable. They reflected only phenomenal "essence" of what the late Heidegger 1930s called the machination (Machenschaft), and very soon he used the fundamental word according to the end of metaphysics - enframing (Gestell). Since its main argument would be that all forms of political discernment with technology in the planetary world democratic, fascist and Bolshevist - are merely "mixed forms and façades." [27].

War is challenging and hence the term "strategy" in the "total war" era is more than semantic excessive meaning. The word is not related at all in the long-term planning implementation of an action different to the tactics of how this might at first glance seem. Although the notion of "strategy" has been taken from Bolshevik's discourse made by Lenin in the struggle for the political overthrow of the imperial order of imperial Russia, it seems to be something far more distant than "revolutionary methods and goals." One is a violent struggle against the violent order. In it, the revolutionary methods before and after the takeover of political power translate into an open "civil war" between ideological-political opponents within a territorial determination of nation-state. Yet, something is completely different when Heidegger in the Leninist view of communism sees a metaphysical framework of one way of confronting the planetary fate of technical mobilization. Precisely for this reason, it should be noted that weapons used in that assemblage have become "strategic". A "total war" in general has become a strategic conflict on the planetary level between the empires and their satellites. Interestingly, even in the political discourse of the "Cold War" of 1945-1989 all including states had to follow the lead of the USSR in previous Warsaw alliance declared "satellite" countries, such as the members of NATO named "allies". This suggests that the US is ideologically and politically 
"democratically constituted" imperial power for the performance of every future war as a "police intervention". And since the permanent condition of the war-and-peaceshapes the forms of "pure war" as a conflict between the obsolete concept of nation-states, then the turn consists in that the notion of terror and terrorism occupies a strategic place of settlement with the "enemy" as "rogue states" that support the network of terror. [28].

When at the horizon disappears metaphysical notion of the world in a whole assemblage of Being -God-World-Man and become replaced by techno-politics of "total mobilization", then this situation can no longer be comprehended by the concept of intermezzo of worlds as Croatian philosopher Vanja Sutlić performed in searching to exit of metaphysics after Heidegger on his path of "historical thinking." [29]. It is the reign of frenzy between Being and event. From this bragging, the prosperity of freedom in the upcoming era does not seem possible from the uncompromising uncertainty of the future. Quite the contrary, we are faced with the construction of an absolute event as the emergence of something that cannot be taken in a causal-teleological way. What does not have its original beginning (arché), that has the lack of meaningful end to all other odds? What's left? Before we come to the clarification of this issue, we must further describe why we can no longer go on with the illusion of war between the nation-states that still ruled in the 19th century, although the very order of the economy, politics and culture was already in the essence of the path of total the mobilization of Europe beyond its own myth of "rootedness" and "homeland", which was especially stated, that the paradox is complete, in the thinking of all three of the decisive German thinkers as the inventors of the planetary mobilization-enframed "world" (Schmitt, Jünger and Heidegger). In the above-mentioned commentary with Jünger and his work in the 1930s when the concepts of "nihilism", "total mobilization", "worker", "total war" Heidegger demonstrate, are not that war/military and militaristic are total mobilizations, which is often misunderstood by Jünger. Quite the contrary, the "essence" of the planetary technology itself is that power should be serious in the "total war". Speaking in a way of Zen-Buddhist terms, a lethal weapon in the hands of the samurai warrior might be not a decoration for the Japanese Shintoist pavilions. The beauty of the sword is imminent to its ultimate purpose: to serve as a weapon of war. So, it is clear why Heidegger's analysis of modern techniques as the enframing (Gestell) presupposes the ability to increase power to an unprecedented scale. The thinking which holds in essence techniques such machinations, pragmatism, calculating, planning and construction necessarily appears, in the end, the instinct and militaristic thinking of the "total war". That is what Heidegger calls the danger (die Gefahr). Power is, therefore, something outside the social framework of human relations. Of course, we are not faced with a question of use or means in the world. It will be possible to find it in the beyond of social relations. In this regard the signifier could be able to act always behind the "facade" just because it is neither total war nor unconditional peace indeed, at all could come to such a constellation of relations without those uncanny power which lies in the will to power as the rule of scientifical-technological subjectivity. [30].

In the posthumously published book Besinnung written in 1938, Heidegger have laid the most radical basis for understanding the end of metaphysics in the realm of being a technique. Even though he had fully developed concept enframing (Gestell) as well as insight into the essence of the art, it is thought exactly on the level of the world-historical situation, which means entering into a completely new era. This applies to new "game rules". Since we are talking about philosophical thinking, it cannot be meaningful to do nothing but a clear-cut order of the categories and concepts with which contemporary science, politics and culture "nowadays" work self-explanatory. Moreover, as we will proactively demonstrate, all the features of the metaphysical endowment are given in terms of order and rank at the same time, and the condition of opportunity for any future understanding of why each return "backwards" emits an illusion and even more, a "reactionary" step in time it relied on an attempt to stop the time of "progress" and "development". This is, of course, an impossible mission. And in its essential features and the reason why the entire project of the German Conservative Revolution in the 1930s was ultimately a result of the failure to deal with the essence of modern technology. Heidegger, as part of the metaphysical discussion, speaks of the five fundamental features of the period of reign "subjectivity" of what we call the global order today:

(1) what is dynamic about power squeeze;

(2) what is totally affecting the principle of power so that nothing outside of that environment can no longer have its innocence and cannot be regarded as "real";

(3) the imperial" that derives from the commanding character of power and invokes any possibility of exception and case in its own environment;

(4) the rationality in which the calculating character of an thinking is confined to the constrained power of execution;

(5) that planetary"which shows that power is no longer just "total" and directed to one state and one nation, but its borders are only within the boundaries of earthly spheres like atmospheres and stratospheres, which means that the planet as a whole is the picture of power can be overtaken in the "penetration" and thus neutralizes possible planetary opponents. [31].

What is decisive point of view to understanding how to perform a technical "world"? All that is already said: dynamics, totality, imperialism, rationality and planetary. The rank of things is apparent from the logic that develops world-historical thickening (implosion) of mass, energy, and speed. The link between the physics of quantum particles and the metaphysical space in which time neutralizes in favor of the simultaneous flow of information, and in this Heidegger's view is truly visible. First of all, what is a dynamic must be finally and planetary? So, otherwise remains only the possibility of action, but not the reality. The notion of the 
planetary-global condition cannot be identical to the Greek original (planétes - around travelling, rocking, pervading into the spheres). The difference is that planetary can no longer leave the self-defense of the earth as in the Ptolemy's notion of the world. [32]. (The earth does not assume the position of the centre of the universe. It is just one of the planets in the Sun's system. Hence the notion of planetary movement must be understood from the essence of modern technology. It is about the construction of the movement as the acceleration of the energy flow required for the transition from the Earth's orbit to the interplanetary order of the worlds. In addition, it might be equally the link between totality and imperialism (all-encompassing and entering into the space of the Empire as "the world state" - Weltstaat) mediated by the fourth member of this pentagram of absolute power. Rationality and rationalization, in fact, derive from the essence of modern natural sciences: mathematics and physics. By the way, Max Weber tried to define the essence of modern society with this concept. Capitalism is impossible without the "prosperity" and "development" of science and technology. The rationalization process denotes the necessity of a bureaucratized life management system in the area of economy, law, politics, and culture. But what is still here, but not expressed, is that the model for the end of metaphysics in the age of the globality-planetary system is indeed somewhat beyond any kind of disposition of nature in terms of subjectivity. Rational knowledge cannot be quite neutral. It invokes the second plan of the mosaic about the ethical thinking that makes things so as they are. What inevitably follows from this total rationality of thought should be "demonic" with this causes and restraints, because totalitarian projects of government and control over human beings are simply a perverted "human nature" in demolishing democratic regimes. The matter is reversed. In essence, totalitarianism was uncanny inhumane. The way that ruling takes place is by turning a man into a thing/creature, lowering it to the lowest rank ever in the grid of concentration camps. That inhumane made him, as Hermann Broch has said it most precisely, "a garbage that is just stinging".

The death factories must be initiated by someone. Without any ethical relation to the dignity of the life of another man, every horrible way of genocide is unimaginable. If the banality of evil is "dwelling" as a routine of everyday life, we are faced with the toughest test of our own conscience. Between the human and the inhuman, the field of ethicalpolitical demands for the defiance of the last forts of the undeniable contingent of humanity escaped. Nowhere else in the love of the neighbor in regard to the face of a person is hiding the feeling of compassion. But the problem here lies in what goes beyond the limits of human and inhumanity. This is an essential difference between the comprehension of total mobilization and the absolute construction. We will see that the first condition of the possibility of the Other, but that at the time of posthuman control and biogenetics can no longer maintain its legitimacy of the term. The reason for this is that it is no longer the result of industrialization (machinery) and the inherent "worker". Quite a contrary, it is represented by time that leaves behind all the figures of modern history, and might be politically signified by entering in the post-imperial sovereignty without fixed subject and without the constant "being." Those who say today that allegedly modern wars may have some kind of defensive character and satisfy the definition of "justice" and "freedom" are only partially right. But the struggle against imperialism as colonialism does not seem to be credible if it is not the same as a movement that carries only another form of "the same" in the ideological-political framework of antiimperialism and anti-colonialism. The problem is that today these concepts have completely lost their meaning. After Arab Spring, instead of the civil revolution against the autocratic political order in the Middle East states, shrank into the Islamic state as a combination of monstrous "political theology" and global terrorism, all overwhelmed. In this respect interesting analysis turnaround from the time the nation in time of culture in the 1980s in the works of Virilio and Baudrillard, because both thinkers note that what "clean war" and "pure terror" transformed into a hybrid of state balance of power and counter-power is nothing previously emphasized. After it became clear that the end of communism in 1989 in a world marked the emergence of a period of uncertainty, chaos and entropy, everything is directed to that balance. [33].

Where does power come from planetary technology? The answer is the following: from the techno-scientific logic of the absolute construction of the event. When all takes on the path of "smart" constructed apparatus from the cities to the economy and mobile phones, is not difficult to conclude that the event designates the formation of "new" must-calculated plan-designed so that if in competition with other try to win with the absolute superiority. It is not relevant here to mention any "market logic". After all, the paradigm of global capitalism should be the right neoliberal order of "rational choice". The markets are not always in the space. They are constructed as a whole virtual reality. Neoliberalism with its ideological-political principles represents, therefore, an assemblage made by cybernetics and libertarians, absolute creativity and meritocracy as the rule of "smart and capable." [34]. The elite who runs and drives global corporations might be all that makes technosphere unique and singular appearance of power, interest, and desire to rule in the corporate governance system of the "world." Never the term "war" is no longer in circulation than nowadays. However, but it goes in a completely different meaning from the frontal conflict between nation-states with their trench battles, negotiations and the conclusion of unjust peace. Aftermath, this applies in particular to (a) corporate "wars"; (b) wars against "terror", (c) cultural or discursive "wars"; (d) cybernetic "wars"; (e) biological "wars"; (f) interplanetary wars as an illustration of future "worlds" and their modes of visual communication. The "wars" inflation testifies the impossibility of war on the ontologically constant determination of the conflict towards peace. Rather than making peace a way to the truth, as the pacifist and 
anticolonial of the indigenous Indian "militant" Mahatma Gandhi once said it, the attitude that is essentially the plan of eternal technique completely neutralizes peace and suspends it. This drives so far that the periods of peace should be, in fact, in the service of the new already programming war. In all possible transformations of the state of affairs, the process of arming takes its place.

\section{Why Is Kant's Postulate of "Perpetual Peace" Ineffective}

The major contributions to the notion of the war from philosophical discourse emerged in the aftermath of the First World War. Apart from the philosophical anthropologist Max Scheler, the work of the French thinker Henri Bergson is particularly worth mentioning. There is no doubt that this conceptual conflict between Germans and French responds to the real state of the horrified horrors from which the leading European countries have emerged deeply traumatized. After all, Ernst Jünger's most significant writings clearly show how much the "experience" and "accomplish" of death are faced with the last moments of human heroism by the ecstasy of the nihilistic adventure. [35]. (The whole "metaphysics of the war," as Scheler explained, is not a mere destruction of nature and culture. It must not be remedied by something truly modern in the experience with which modernity leads to the ultimate consequences of the apocalyptic consciousness of the end of the idea of "progress" and "development". The fundamental determinant of the industrial society of the world-historical adventure of capitalism is that a system in which everyday life is extradited to the grace and helplessness of repeating boredom, the routine of ordinary, the empire of banality. The machine in the mechanical part of the action cannot be without the human share. But what Freud calls "human prosthesis," which refers to the sublime object of culture, is turning to the ontological site of man and machine. Now human beings are being mechanized. That way it becomes prosthesis of the inhuman. In the book entitled Genius of War and the German War (Den Genius des Krieges und den Deutschen Krieg) in 1915, Scheler speaks of the war that allows the disillusionment of truth. Its "organization", "legal form", and "purposes" are essentially opposed to the daily flow of life as a normal course of work and leisure. [36].

If we exclude the fact that the entire neo-Kantian philosophy has been ethically-esthetically derived from the so-called ethical values and the notion of aesthetic experience, it will be clearer why Jünger's literary success with the record of war experiences on the front should be the result of a combination of Nietzsche's rhetoric of nihilism, superhuman and personal war adventures. After all, this way of saying, outlining all the terms of radical criticism of conditions that lead to war, is what links psychology and metaphysics to "border situations" and "extraordinary states". The most important thing, however, is something else. The war should be phenomenologically exposed as an event that does not arise in advance from the evil of human nature, and cannot be removed by the ethical set of measures from the world's historical destiny of Being itself. In this regard, the attitude of Jan Patočka, a Czech phenomenologist and a famous dissident in the struggle against communist totalitarianism, represented the condition of any further discussion of the relationship between techno-science, new ethics and politics to face the total war "now" and "in the future":

"In the new relationship between atomic weapons and constant threats with total destruction, the glowing war may become cold or smoulder. The smoulder war is no less cruel, and it is often even crueler than the glowing one, in it the battles are lurking on continents. It has already been shown that war itself involves 'peace' in the form of demobilization. On the other hand, permanent mobilization represents fatum that the world is severely endured, hard to look at in the face..." [37].

The problem that arises from the exposure of the war as an "event" with which the individual has to be exaggerated in the whirlwind of uncompromising events does not affect just the spheres of "values" and "experiences". Since modernity in its "being" as unsustainable movement of science and technology towards the future in the transformations of forms and characters, it is obvious that the war between nationstates must be transformed into the "total war" of the imperial order of the states. There is no doubt that the time loses the type of "heroic realism" and nationalism-patriotism that German-French philosophers and writers paraded after the First World War. What, however, remains unclear to date today: how can philosophical comprehend the phenomenon of war in its "purity" if the first assumption of the end of metaphysics is that Clausewitz's definition, as Heidegger has clearly shown, no longer applies to the totality and planetary of the 20th-century war? If it is no longer valid that the war is a continuation of politics by other means, then it is clear that politics is not a continuation of the war by other means. Both war and politics come from something that allows them in their relationship. The political, as Carl Schmitt knew very well, cannot be right in any way to be insignificant from the devastating influence of other spheres such as science, technology, society, economics, culture, religion unless it is constituted as an exceptional event of "revolution" in the very world of modernity. Of course, the problem with such a "revolution" is not just another face of violence that has shaken the world of the collapse of liberal-democratic order in the 20th century with the arrival of Nazism in Germany, fascism in Italy, and Stalinist communism in Russia. What the political in itself holds as the bragging of the greatest freedom of opportunity denotes the existential project of overcoming death. The heroic act of a singular individual to oppose the order of organized evil in the form of the totalitarian state as in the case of Patočka, is still a little more than the sacrificial act of his own life. As far as this impossibility is concerned, what emerges from this sacrifice of liberty shows that war and politics are only a continuation of planetary techniques by other means. Continuation does 
not mean a mere extension of the unbroken line. So-called "other means" are not a mere instrument of performance. It is better to say that the political one has simultaneously a "demonic" and "emancipatory" potential. So, therefore the question of the essence of war in the era of the end of metaphysics might be simultaneously the question of being political at the time of the end of history. Nothing is more autonomous precisely because the singular event of technosphere is one that every thought of autonomy of action without facing the conditions of radical change of state is removed from the game as the "naive", "illusion", "idealism". Among the demands for absolute freedom and the net of total power, there is a gape, a deep abyss. Solely that testifies the inability to act without a radical change of thinking. Heidegger was right, then, in thinking of "the Second Beginning" and the event (Ereignis) that

"No 'revolution' is 'revolutionary' enough." [38].

What can stand against this normative delirium of political philosophy? However, even today there is considerable pathos in theories of different currents ranging from neomarxism of Badiou and Rancière to Agamben's criticism of biopolitical production of power in the traces performed by Foucault, Benjamin and Schmitt. One of the reasons for the rise of the political concept in the contemporary debate over politics must be concealed in the fact that it is a controversy between the openness of freedom towards the closeness of total power distributed over and beyond the global order of power. On the one hand, there is no political power to deal with the techno-scientific logic of crossing the war into the "state of emergency" of strategic armaments and threats to "weak states", as we can see in the inability to radically calculate the global order of multipolarities (USA, Russia, China) with the nuclear power of North Korea. But, on the other hand, we are witnessing the fact that so-called liberaldemocratic order leads to a constant "preventive-defensive" wars. A ruthless network of terror is embodied today in the Islamic State where are formally involving the NATO alliance and Russia (however, in a conflict with a high level of involvement). Between the norms and the actions, there is a deeper gap than it was existed in the golden age of the "Baroque order of the states." What is the reason for this? It seems to me that there is no longer any certainty about the political foundations of a "universal world state" which would be a guarantee of termination of war conflicts. Moreover, there is not even a willingness to give up on the remnant of the sovereignty that belongs to the last settlements of international law based on an understanding of the obsolete nation-state. The question of the credibility of contemporary thinking about war is passing or falling precisely in explaining why we can no longer speak about "eternal peace" which, with Kant's postulate of the cosmopolitan order, enlightened the idea of perfecting the mind to the ethical obligation of removing the "eternal war". Whenever a discussion is made about whether the so-called "human nature" is always good or evil, the uncanny end to the surface is indefinite. This is nothing but the question of the ontological difference between animals, humans and machines. In other words, humanity becomes the fundamental criterion for evaluating the ability of an animal to be pitiful or wild, and the machine as inhumane in principle is understood ethically neutral. We see that this could be relevant to the emergence of cybernetics and informatics. Since then, the machine has emerged as an "artificial intelligence" (AI) and essentially changes the metaphysical order and the rank of Being, beings and being human. Some of the leading cosmological scholars, as well as theoretical physicists, predict that the "total war" on the upcoming age of planetary total mobilization should be a kind of "rebellion inhuman" in the form of government of the living machine. Therefore, it seems necessary to once more re-examine the reach of Kant's postulate without which every attempt of the thought of "eternal peace" remains on and beyond the dead letter on paper.

As it is known in the book Zum ewigen Frieden. Ein philosophischer Entwurf (Perpetual Peace: A Philosophical Essay) in 1795, Kant's thesis, within its political philosophy, is based on the fact that moral action signifies a condition to the possibility of politics. In one place of this famous essay, we find the following statement:

"Politics in the real sense cannot take a step forward without first paying homage to the principles of morals."[39].

Though Kant constantly recalls the problem of the survival of evil and good in the notion of "human nature", starting from the transcendental principles of the idea of man as an animal rationale, the intention of his thought project, in which the essence of the European Enlightenment reached its peak, is at first glance primarily political-legal. So, that the world history of the wars and bloody revolutions could calm down within the space of mind, reason, and controlled passions, as well as that the idea of providential God could find its true place in historical events, the "perpetual peace" between the peoples and the state really does in the process of becoming the world order of the universal state constructed on the fundamentals of the mind. In other words, Kant assumes that the only necessity is not the one in its nature as the empire of chaos and disorder, but rather in the culturally perfect cosmopolitan order of the "world". There is room here for all people - but only with the mutual recognition of the moral subjects of the political suspension and the neutralization of the sovereignty of nation-states. This, of course, does not mean the end of the state in the political sense. It still has its own power and scope of protection of personal freedom and civil security. However, the problem is that the idea of a cosmopolitan order cannot be achieved without a parallel process, speaking with modern words, "depoliticizing and neutralizing" the state as an instrument of violence, power and, ultimately, those who run the war machine. [40]. (If we remove any implication of hopeless philanthropy standing in the throes of ideas of "perpetual peace," which is Kant's own criticism of his own political philosophy, then something much more complex still remains. It's about the right to hospitality which includes hospitality towards the other and the right to asylum for foreigners if the state instead of expressing its affections and 
taking over the obligations of civil duties becomes the object of endangering its institutions. Well, it does not seem necessary to mention in particular how much this dossier is due to highlighting political federalism, the legal articulation of the law on hospitality and asylum for foreigners and refugees today. In contemporary philosophy in the late ethical-political turn of Levinas and Derrida, the question of sovereignty, foreigners, refugees, as well as European constitution of citizenship appears crucial for the future of Europe and the world at large. [41].

Whence, however, the theoretical urge to build the cosmopolitan order of the "world" and the resulting necessity of "perpetual peace"? Kant must assume something simultaneously theologically defined and philosophically determined by the entire metaphysical tradition of thought. This is nothing but the idea of Christian theodicy. With the beginning of the innocence of nature, then original sin and falling in the state of evil with which historical event takes place in the conflicts and wars in recognition of the entity (individual, nation and state), and, finally, redemption and enlightenment exaltation to the highest possibilities that the man given a come from his mind to the ability to create and perfect the moral order of good and righteousness. Kant's explanation of this necessity of "progress" and "development" of history from the natural state to the social contract and the emergence of the Republican order of nation-state up to the "world state" that will be a guarantee of "religious peace" is quite a strange connection between the demands of the mind moral postulate and grace of providence (nature). Namely, what is missing in this paradoxical connection between the rational order of the universality of rights "world state" and religious nature in itself is in the sphere of what Aristotle called friendship (philia) in the community. From the new era until today the life has kept the floor called solidarity in communion. In both cases, it is not about the right subject to their own impetus and aspirations. Instead, the Republican political order needs a kind of "civil religion" of freedom. Its function must be integrative in creating cosmopolitan order. But the problem is how effective this term is along the way. Certainly, because there is no solidarity between nations and states in the existing constellation of power, which only occurs in the afflictions and disadvantages of endangered humanity such as natural disasters and after the fatigue of "total war", Kant must, therefore, postulate communion, starting with the teleology of historical events:

"The intercourse, more or less close, which has been everywhere steadily increasing between the nations of the earth, has now extended so enormously that a violation of right in one part of the world is felt all over it. Hence the idea of a cosmopolitan right is no fantastical, high-flown notion of right, but a complement of the unwritten code of lawconstitutional as well as international law-necessary for the public rights of mankind in general and thus for the realisation of perpetual peace. For only by endeavoring to fulfill the conditions laid down by this cosmopolitan law can we flatter ourselves that we are gradually approaching that ideal." [42].

\section{Conclusion}

What happened to the idea of "perpetual peace" which does not move from a moral postulate to a condition of political-legal realization? We have seen that instead of the purpose and legitimacy of history, contingency and the singularity of what is indefinite after the "end of history" is at work here. If, therefore, Kant remains in his enlightenment program with the indisputable proof that philosophy in relation to reality refers to a norm in relation to action, then the turn to be counted in the permanent condition of war and peace represents a sort of defeat of the Enlightenment in the face of the reign of planetary technology. The problem should not be obviously performed in moral postulates concerning the upcoming era as the absence of the results of God's providence, which was based on the idea of mind's nature and its ultimate purpose. Conversely, the problem lies in the fact that the real "total war" is the paradoxical link between total mobilization of the techno-science and the absolute construct of the event which changes the Being from the very foundation. War as a synthesis of the modern impact scheme performed by calculating-planning-construction to the possibility of total devastation and destruction of the human species on earth, however, is active in itself. Hegelianic spoken, but with inevitable cynicism - we are faced with the cunning of the astonished mind. What does that look like? None other than in the intimidation of the Other and self-asserting that nation-states are still leading the post-imperial wars of oil, gas, water, faith, human rights, freedom of the people, etc. It has been long ago since that what matters was over. When is the subject of outdated political and legal games in the will to power is cleaned of all trace of "patriotism" and "nationalism", what is still left? Obviously, only naked power contained in the mood for the rule of impersonal, of what in contemporary philosophy after Heidegger and Deleuze exposes as self-posture network relations no longer have any centre, not even the edge. The replacement might be reduced only to a multitude of hubs in constant self-repair at all a higher level of intensity the destructive power. "Total war" knows no winners and defeat simply because it requires a constant renewal capacity needed for the entire implosion of core concerning to the new planetary conflict. However, this is not at all the essence opposed to Kant's "perpetual peace," though now without any moral postulates, but with a pragmatic solution to the ongoing negotiations on the end of the conflict. Instead, everything goes in the other direction, but no longer in the downward turn. Orientationally, the direction of transversal movements is like the wars that are currently clashing between the decentralized network of empires and their noncounterattacks of power. Ranking and structures category in this order shows that the state terror in the form of a "police action" towards the rogue states has its reaction in the form of terror of the Islamic state. It is a terror that is no longer a means for the purpose of building a "new totalitarianism". 
The fundamental purpose of this terror is to "obey" the open societies of Western civilization to what is threatening each order of liberty and republican values of democracy. But because absolute terror is undeniable to politics as a strategy game of power that becomes the act of totalizing in wars and threats to the other, it is possible to ask the question of the boundary between the end of the world-historical drama of the West and the beginning of the global-planetary agony of the empire and their satellites. Wars are not an extension of technology that enables new ideas to emerge. In this regard, the end of metaphysics is at the same time the end of history as a meaningful flow of ideas from Greek to cybernetics. Ernst Jünger in the World State (Der Weltstaat) revealingly points to the end of the epoch determined "world history". Its flywheel was the freedom and will for the nascent spiritual world of shaping the ideal figure of a civilization that unites Greek ideas of philosophy and art. History hence exemplifies the departure from mythical and chaotic nature into the formative structure of the development of spiritual powers. When they are no longer in the centre, the "remembrances and prostheses" of what was once authentic and alive are left of "world history". What, then, is left of the idea not only of world history, but also of the different versions of the "just war" in a time when terror, total control and biopolitics decide on events in the world? The answer lies not in the pseudo-humanization of the world and the inflation of ethical doctrines as a therapy for the frenzy of the technologically constructed apocalypse.

Instead of utopia and apocalypticism, the solution lies in contemplating the very constellation of techno-cybernetic thinking as the danger that this condition allows - between "total mobilization" and "absolute construction". The thinking belongs to an event without which it is in its technical destiny that it remains halfway between emptiness and nothingness. Do we still have a thinking which should be appropriate to the controversy of the "military thought" that has emerged from Western metaphysics and all of its sciences? It is not difficult to answer that question. We have, of course. But it is without power because thinking no longer decides on the fate of the upcoming events. Instead, everything is definitely in the hands of a techno-genetic absolute construction. Everything is, ultimately, the question of a decision about the odds of a completely different path than the one which appears in the signs of an uncanny "necessity". We do not choose "us" or "they" on this decision. Quite the contrary, the final decision belongs to "one" that is concealed in the "being" of calculating-planningconstruction but always of one and the same event. Can this decision be delayed or avoided in its "necessity" and "inevitability"?

\section{References}

[1] Jünger, Ernst (1931) Die total Mobilmachung. Berlin: Verlag fur Zeitkritik.

[2] Agamben, Giorgio (2003) The Open:Man and Animal.
Stanford, CA: Stanford University Press. (Translated from Italian by Kevin Attell).

[3] Kojève, Alexandre (1980) Introduction to the Reading of Hegel, (ed. Allan Bloom). Ithaca, N. Y.: Cornell University Press. (Translated from French by James H. Nichols, Jr.). 158159.

[4] Sloterdijk, Peter (1999) Regeln für den Menschenpark: Ein Antwortschreiben zu Heideggers Brief über den Humanismus. Frankfurt/M: Suhrkamp.

[5] Schmitt, Carl (1996) Der Begriff des Politischen. Berlin: Duncker \& Humblot.

[6] Heidegger, Martin (2014) Überlegungen XII-XV (Schwarze Hefte 1939-1941), GA, vol. 96. Frankfurt/M: V. Klostermann. 152.

[7] Hegel, Georg WF (1974) "Über die wissenschaftlichen Behandlungsarten des Naturrechts" in Frühe Politische Systeme. Frankfurt/M. - Berlin - Wien; Ullstein. 103-199.

[8] Sloterdijk, Peter (2006) Zorn und Zeit: Politischpsychologischer Versuch. Frankfurt/M: Suhrkamp.

[9] Paić, Žarko (2013) Freedom without Power: The Politics of Entropy Network. Zagreb: White Wave.

[10] Meier, Christian (1973) Die Entstehung des politischen bei den Griechen. Frankfurt/M: Suhrkamp

[11] Heidegger, Martin (2004) Zu Ernst Jünger, GA, vol. 90. Frankfurt/M: V. Klostermann. 264.

[12] Paić, Žarko (2011) Posthuman Condition: The End of Man and Odds of Other History. Zagreb; Litteris.

[13] Zourabicvili, François (1994) Deleuze - Philoisophie de l'évenément. Paris: Presses Universitaires de France; van Tuinen, Sjoerd and McDonnell, Niamh (eds.) (2004), Deleuze and the Fold: A Critical Reader. Palgrave MacMillan; Davis, Martin (2000) The Universal Computer: The Road from Leibniz to Turing. New York: WW Norton \& Comp.

[14] Jünger, Ernst (1981) Der Arbeiter - Herrschaft und Gestalt. Stuttgart: Klett-Cotta. 153.

[15] Paić, Žarko (2016a), "Technosphere - A New Digital Aesthetics? The Body as Event, Interaction and Visualization of Ideas "in Paić, Žarko and Purgar, Krešimir (eds.). Theorizing Images. Newcastle upon Tyne: Cambridge Scholars Publishing. 126-148.

[16] Schmitt, Carl (1997) Der Nomos der Erde im Völkerrecht des Jus Publicum Europeeum. Berlin: Duncker \& Humblot.

[17] Mohler, Armin and Weißmann, Karheinz (2005) Die Conservative Revolution in Deutschland 1918-1932. Graz: ARES Verlag. Issue 6 and Grossheim, Michael (2002) Politischer Existenzialismus: Subjektivität zwischen Entfremdung und Engagement. Tübingen: Mohr Siebeck.

[18] Paić, Žarko (2015) "Metapolitics and Evil: About Heidegger's" Spiritual Nazism", in Totalitarianism? Zagreb: Meandarmedia.. 135-206.

[19] Nossack, Hans Erich (2004) THE END: Hamburg 1943. Chicago: University of Chicago Press. (Translated from German by Joel Agee) and Sebald, WG (2003)

[20] Jünger, Ernst (1981). 99. 
[21] In both cases, as evident in the Soviet occupation and attempted conquest of Afghanistan in the 1980s, and the US military intervention in the fight against the Taliban as part of the "war on terror" (Afghanistan and Iraq), the differences in ideological-political and the strategic goals of the imperial forces are evident. But they are not of particular importance because it is only a different way of conquering a sovereign and independent state. Therefore, to to talk about contemporary forms of wars between global empire (the United States and Russia) and their satellites in the 21st century against "rogue states" (rogue states), it is necessary to separate three levels of speculative-reflexive considerations of what is being done here as a singular event of war: (1) the geopolitical and strategic level of occupation of the country as a space for all available resources (water, oil, gas, noble metals); (2) the ideological-political level of governmentality in "warfare-information-communication protocols"; (3) selfdetermination of total power in the absolute structure of an event in which a war from the military-political conflict moves into the dimension of the permanent condition. And this state can be called a stand-by position. There are many posthumanists/transhumanists claiming that Silicon Valley is more important than Valley of Kings or Arab Deserts for upcoming interplanetary exodus and "star wars". See AlRodhan, Nayef (2009) Neo-statecraft and Meta-Geopolitics. Reconciliation of Power, Interests and Justice in the 21st Century. Zürich: LIT.

[22] Schmitt, Carl (2006) Theorie des Partisanen: Zwischenbemerkung zum Begriff des Politischen. Berlin: Duncker \& Humblot, Berlin.

[23] Jünger, Ernst (1960) Der Weltstaat. Stuttgart: Klett-Cotta.

[24] Deleuze, Gilles and Guattari, Felix (1987) A Thousand Plateaus: Capitalism and Schizophrenia II. London and New York: Continuum. (Translated from French by Brian Massumi)

[25] Virilio, Paul and Lothringer, Sylvère (1998) Pure War. New York: Semiotext.

[26] Virilio, Paul (2000) The Information Bomb. London and New York: Verso. (Translated from French by Chris Turner).

[27] Heidegger, Martin (2004) Zu Ernst Jünger. 231.

[28] Sutlić, Vanja (1988) How to Read Heidegger: Introduction to the problematic Level of "Sein und Zeit" and Related Works. Zagreb: August Cesarec.

[29] Derrida, Jacques (2005) Rogues: Two Essays on Reason. Stanford, CA: Stanford University Press. (Translated from French by Pascale-Anne Brault and Michael Naas).

[30] Heidegger, Martin (2004) Zu Ernst Jünger. 232.

[31] Heidegger, Martin (1997) Besinnung. GA, vol. 66. Frankfurt/M: V. Klostermann.

[32] Sloterdijk, Peter (1986) Kopernikanische Mobilmachung und ptolemäische Abrüstung. Frankfurt/M: Suhrkamp.

[33] Paić, Žarko (2017) The Age of the Oligarchy; From Information Economy to the Politics of Event. Zagreb: Litteris.

[34] Virilio, Paul (2005) L'accident originel. Paris: Galilée and Baudrillard, Jean (1993) Der reine Terror: Gewalt von Rechts. Wien: Passagen.

[35] Jünger, Ernst (1926) Der Kampf als inneres Erlebnis. Berlin: ES Mittler \& Sohn.

[36] Scheler, Max (1982) "Der Genius des Krieges under Deutschen Krieg" in Gesammelte Werke. Bern-München: Francke.

[37] Patočka, Jan (2015) "Heretic Essays on the Philosophy of History", European Messenger. No 20. 612. (Translated from Czech to Croatian by Matija Ivačić).

[38] Heidegger, Martin (1998) Die Geschichte des Seyns. GA. vol. 69. Frankfurt/M: V. Klostermann.

[39] Kant, Immanuel (1903), Perpetual Peace: A Philosophical Essay. London: Georg Allan \& Unwin Ltd. (Translated from German by Campbell M. Smith, M. A.). 182-183.

[40] Archibugi, Daniele (eds.) (2003) Debating Cosmopolitics. London-New York: Verso.

[41] Paić, Žarko (2016b) Refugee Cities: From Ethics of Hospitality to Friendship Policy (Lévinas-Derrida. Zagreb: Pan Liber and Institute for European and Globalization Studies.

[42] Kant, Immanuel, (1903). 142. 